Transactions of the VŠB - Technical University of Ostrava, Mechanical Series

No. 1, 2015, vol. LXI

article No. 1997

\title{
Štefánia SALOKYOVÁ* \\ MEASURING THE AMOUNT OF MECHANICAL VIBRATION DURING LATHE PROCESSING
}

MERANIE VELKOSTI MECHANICKÉHO KMITANIA PRI SÚSTRUŽENÍ

\begin{abstract}
The article provides basic information regarding the measurement and evaluation of mechanical vibration during the processing of material by lathe work. The lathe processing can be characterized as removing material by precisely defined tools. The results of the experimental part are values of the vibration acceleration amplitude measured by the piezoelectric sensor on the bearing house of the lathe. A set of new knowledge and conclusions is formulated based on the analysis of the created graphical dependencies.
\end{abstract}

\begin{abstract}
Abstrakt
Článok poskytuje základné informácie o meraní a vyhodnocovaní mechanického kmitania pri obrábaní materiálu sústružením. Sústruženie možno charakterizovat’ ako odoberanie materiálu presne definovaným nástrojom. Výsledkom experimentálnej časti sú namerané hodnoty amplitúdy zrýchlenia vibrácií pomocou piezoelektrického snímača na ložiskovom domci sústruhu. Na základe analýzy vytvorených grafických závislosti je sformulovaný súbor nových poznatkov a záverov.
\end{abstract}

\section{Keywords}

Lathe processing, mechanical vibration, vibration acceleration amplitude, frequency, frequency spectrum.

\section{INTRODUCTION}

The article provides basic overview of the vibration diagnostic, as a method which serves for early diagnosis of the damage, through the analysis of measured vibrations on given device. The bases for the diagnostic evaluation methods are especially objective and qualitative data about the monitoring system, which we gather either by a one-time measurement or permanent monitoring. Early discovery of the arising defect has a great influence on the fluency and effectiveness of the production. In our case one of the three characteristic values was used for the diagnosis of the mechanical vibration, namely the acceleration of the vibration. The vibration is an undesired occurrence during processing; therefore one needs to deal with this topic more frequently [1 -4].

The article observes the amount of vibration on the bearing house of a turning lathe selected in advanced through the change of the rpms and the thickness of the removed material in frontal type of lathe processing.

* Ing. Štefánia Salokyová, PhD., Faculty of Manufacturing Technologies, Department of Manufacturing Processes Operation, Technical University of Košice, Bayerova 1, 08001 Prešov, Slovakia, tel. (+421) 55602 6337, e-mail stefania.salokyova@gmail.com 


\section{CONDITIONS OF THE EXPERIMENTS}

The experiments were performed in the laboratory of splint processing on alloy type construction steel of the type STN 11503 class 11.The Fig. 1 displays the material before and after the processing. Six independent measurements were performed, split into three experiments. Initial constant and changing parameters under which the experiments were performed are stated in Table 1 [6].

Tab. 1 Conditions of the experiments

\begin{tabular}{|l|c|c|c|c|}
\cline { 2 - 4 } \multicolumn{1}{c|}{} & $\begin{array}{c}\text { constant } \\
\text { parameters }\end{array}$ & \multicolumn{2}{|c|}{ changing parameters } & \multirow{2}{*}{ output } \\
\cline { 2 - 4 } \multicolumn{1}{c|}{$\begin{array}{c}\text { type of } \\
\text { material }\end{array}$} & $\begin{array}{c}\text { the reduction of } \\
\text { the material }\end{array}$ & motor speed & \\
\hline 1. experiment & \multirow{2}{*}{11503} & $0 \mathrm{~mm}$ & $800 \mathrm{a} 1200 \mathrm{rpm}$ & \multirow{2}{*}{$\begin{array}{c}\text { vibration on the } \\
\text { bearing housings }\end{array}$} \\
\cline { 1 - 3 } 2. experiment & $11500 \mathrm{a} 1200 \mathrm{rpm}$ & $800 \mathrm{a} 1200 \mathrm{rpm}$ & 3. experiment \\
\cline { 3 - 4 } & & $2 \mathrm{~mm}$ & &
\end{tabular}
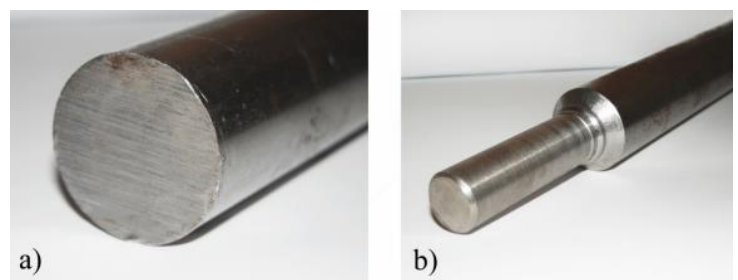

Fig. 1 Material before and after processing

\section{SPECIFICATION OF THE TECHNICAL SYSTEM DURING THE MEASUREMENT AND EVALUATION OF THE VIBRATION}

A piezoelectric sensor of the type 4507B-004 from the Brüel \& Kjaer Company was used for the monitoring of the frequency analysis of the vibration, which was attached to the bearing house of the lathe TOS SV 18RB through magic glue (Fig. 2). The piezoelectric sensor of the vibrations monitors the vibrations during the processing in the direction of the lathe processing axis. The data collector records the acceleration of the vibration signal and integrates it with the speed of the vibration signal [6].

Vibration acceleration amplitudes recorded in the axis of the lather processing in this way are written into the memory of the Compact DAQNI 9233 device of the National Instruments Company and are evaluated in the frequency spectrum through the means of a quick Fourier transformation. This allows determining the quantity of the harmonic frequencies in the monitored signal. The evaluated signal can then be immediately observed on a portable computer thanks to the SignalExpress software. The SignalExpress program contains several functions necessary for the proper evaluation, recording and analysis of the measurements [6].

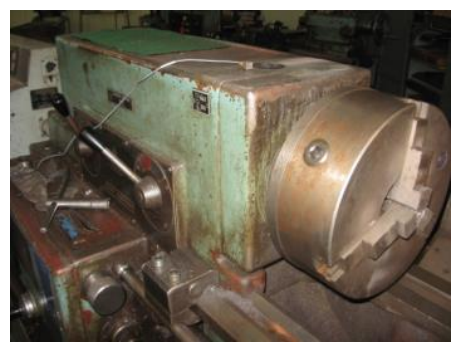

Fig. 2 Attachment of the vibrations sensor on the bearing house of the lathe 


\section{MEASURED VALUES OF THE EXPERIMENTS}

The vibration signal measured during the processing and during the time period is transformed through the means of a quick Fourier transformation to the frequency spectrum in the range $3.0-$ $10.0 \mathrm{kHz}$. The graphic dependencies of the vibration acceleration amplitude course changes depending on the frequencies are evaluated together for 800 and 1200 motor rpms. The vibration acceleration amplitude course changes for frequencies of 800 and 1200 motor rpms and material removal of $2 \mathrm{~mm}$ are graphically displayed as an example in Fig. 3.

Graphical dependencies of the vibration acceleration amplitude and vibration frequencies for 800 and $1200 \mathrm{rpm}$ without load and with material removal of $1 \mathrm{~mm}$ have been also analogously displayed.

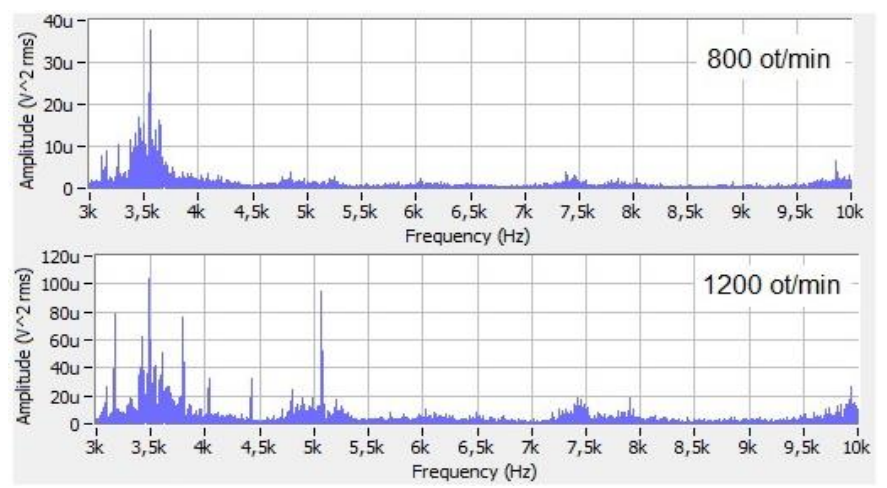

Fig. 3 Graphical dependency of the vibration acceleration amplitude on the frequency with material removal of $2 \mathrm{~mm}$

Based on the graphical dependencies of the vibration acceleration amplitude, covers of the frequency spectrum of the vibrations on the bearing housing have been created, and based on them, comparison charts of the frequency covers spectrums for the common set of experiments have been created. Fig. 4 depicts the comparison chart of the frequency spectrum covers together for the selected examined set of spindle rotations of 800 and $1200 \mathrm{rpms}$ without load. The comparison chart of the frequency spectrum covers for the motor rotations of 800 and 1200 rpms with material removal of $1 \mathrm{~mm}$ is depicted in Fig. 5 and with material removal of $2 \mathrm{~mm}$ in Fig. 6.

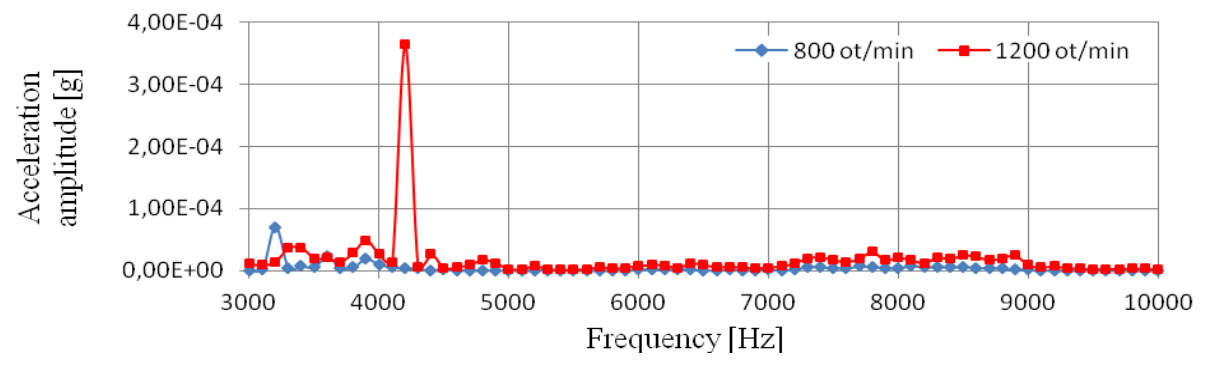

Fig. 4 Comparison chart of frequency spectrum covers without load for 800 and $1200 \mathrm{rpms}$ of the motor 


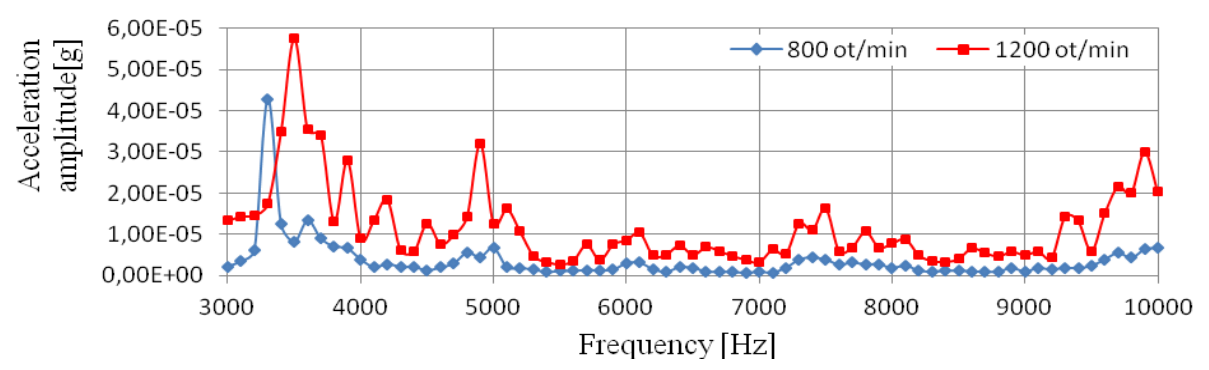

Fig. 5 Comparison chart of frequency spectrum covers with removal thickness of $1 \mathrm{~mm}$ and 800 and 1200 rpms of the motor

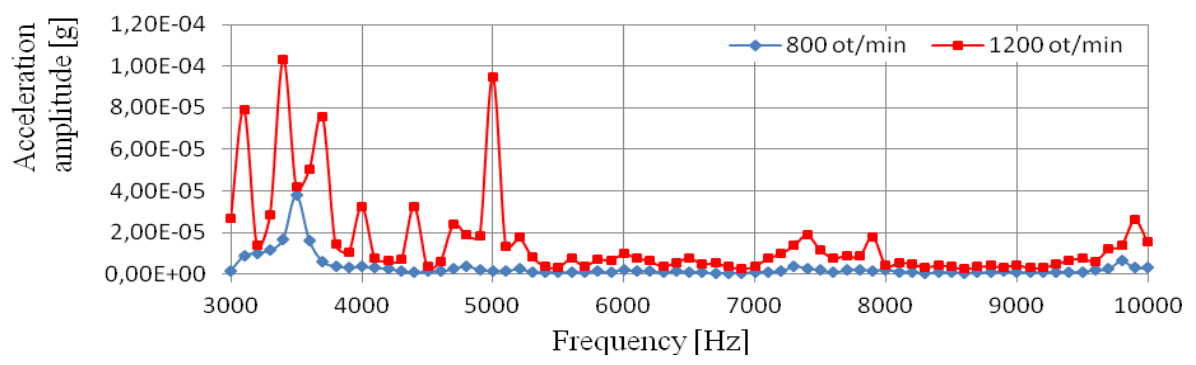

Fig. 6 Comparison chart of frequency spectrum covers with removal thickness of $2 \mathrm{~mm}$ and 800 and 1200 rpms of the motor

Chart of the maximum vibration acceleration amplitude values is created based on the comparison charts of the frequency spectrum covers (Tab. 2).

Tab. 2 Maximum vibration acceleration amplitude values

\begin{tabular}{|c|c|c|c|}
\hline \multirow{2}{*}{ motor speed } & \multicolumn{3}{|c|}{ maximum values of the vibration acceleration amplitudes [g] } \\
\cline { 2 - 4 } & 1. experiment & 2. experiment & 3. experiment \\
\hline $800 \mathrm{rpm}$ & $7,05.10^{-5}$ & $4,29.10^{-5}$ & $3,78.10^{-5}$ \\
\hline $1200 \mathrm{rpm}$ & $3,64.10^{-4}$ & $5,76.10^{-5}$ & $1,44.10^{-5}$ \\
\hline
\end{tabular}

The results of the experiments contain also the evaluation of the comparison charts of the frequency spectrum covers in the structure independently for the two examined rpms and together for the material removal. The comparison chart of the vibration acceleration covers and vibrations frequency spectrums of the bearing house for $800 \mathrm{rpms}$ and material removal of 1 and $2 \mathrm{~mm}$ is depicted in Fig. 7 and Fig. 8 depicts the comparison chart for 1200 rpms.

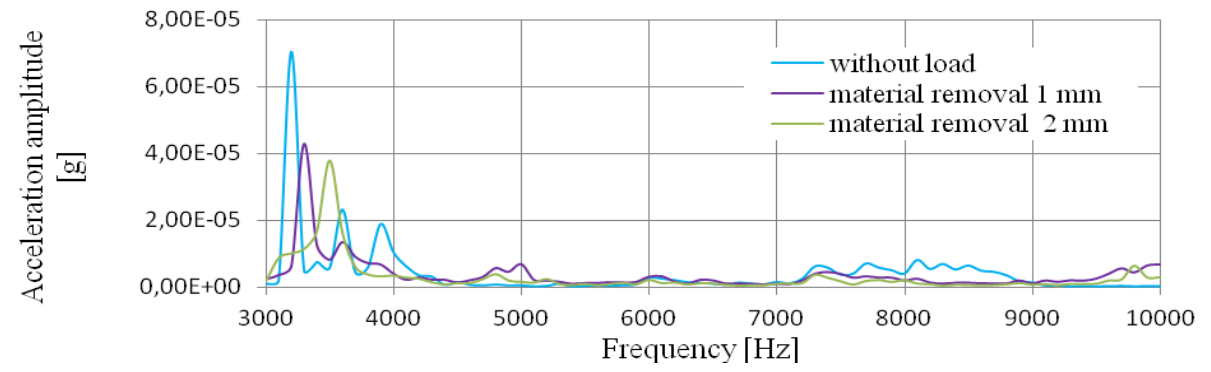

Fig. 7 Comparison chart of the frequency spectrum covers with material removal of 1 and 2 $\mathrm{mm}$ and at $800 \mathrm{rpms}$ 


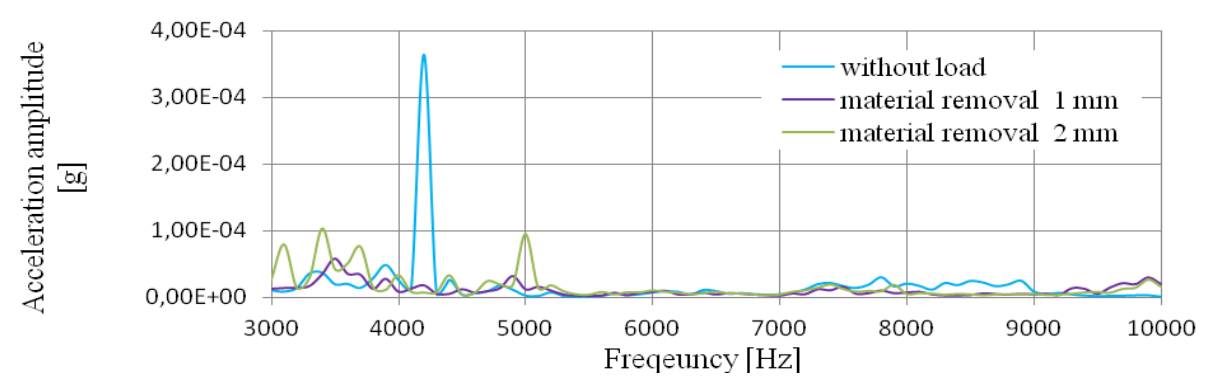

Fig. 8 Comparison chart of the frequency spectrum covers with material removal of 1 and 2 $\mathrm{mm}$ and at $1200 \mathrm{rpms}$

\section{DISCUSSION}

The article deals with the effect of lathe motor's rotations and the factor of thickness of the removed material from the processed material on creation of mechanical vibration in the bearing house of the lathe during processing and the results are new knowledge and recommendations:

- with two examined motor rotations of 800 and $1200 \mathrm{rpms}$ and material removal of 1 and $2 \mathrm{~mm}$, the increased vibrations values in the examined range $3,0-10,0 \mathrm{kHz}$ are found in the frequency spectrums 3,0 through $5,0 \mathrm{kHz}$

- the size of the vibration acceleration amplitude without load in the comparison range reaches the highest value 3,64.10-4 $\mathrm{g}$ at frequency $4,2 \mathrm{kHz}$ and $1200 \mathrm{rpms}$

- with the growing numerical value of the motor's rotations without load in the examined range, the value of the vibrations accelerations amplitude increases and when compared to the 800 rpms and 120 rpms grows $80,63 \%$

- the size of the vibration acceleration amplitude with material removal of $1 \mathrm{~mm}$ in the comparison range reaches the highest value 5,76.10-5 $\mathrm{g}$ at frequency 3,5 $\mathrm{kHz}$ and $1200 \mathrm{rpms}$

- with the growing numerical value of the motor's rotations and material removal of $1 \mathrm{~mm}$ in the examined range the value of the vibrations acceleration amplitude grows and when compared to the $800 \mathrm{rpms}$ and $120 \mathrm{rpms}$ grows $25,52 \%$

- the size of the vibration acceleration amplitude with material removal of $2 \mathrm{~mm}$ in the comparison range reaches the highest value $3,78.10-5 \mathrm{~g}$ at frequency $3,5 \mathrm{kHz}$ and $800 \mathrm{rpms}$

- with the growing numerical value of the motor's rotations and material removal of $2 \mathrm{~mm}$ in the examined range the value of the vibrations acceleration amplitude grows and when compared to the $800 \mathrm{rpms}$ and $120 \mathrm{rpms}$ grows $61,90 \%$

\section{CONCLUSIONS}

The above results show that with the increasing speed of the rotation, the values of the mechanical vibrations gradually grow. With increasing thickness of the removed material the values of the vibrations acceleration amplitude have decreased. From the perspective of optimizing the process of turning on a lathe TOS SV $18 \mathrm{RB}$ it can be stated that it is necessary to avoid rotations of 800 and $1200 \mathrm{rpms}$ when processing without load with respect to the values of the mechanical vibrations. The results achieved indicate continuation of the research, since this work is focused on examining the magnitude of the vibrations on the bearing house of the lathe TOS SV 18RB. Stated 
results form part of experiments comparing the input parameters and their suitability for use in turning conditions.

\section{REFERENCES}

[1] BUDA, J. \& SOUCEK, J. \& VASILKO, K.: Teória obrábania. Praha: ŠNTL, 1988, 356 pp. ISBN 80-7789-14-6

[2] BENO, J.: Teória rezania kovov. Košice: Vienala, 1999, 260 pp. ISBN 80-7099-429-0

[3] MÁDL, J.: Teória obrabění. Praha: ČVUT, 1990, 156 pp.

[4] KREIDL, M. \& ŠMID, R.: Technická diagnostika, Praha: Ben, 2006, 406 pp. ISBN 80-7300$15-86$

[5] KREHEL, R.: Vibračná diagnostika rotujúcich strojov. MM. Průmyslové spektrum. 2007 No. 7, 8, pp. 29. ISSN 1212-2572

[6] SALOKYOVÁ, Š.: Analýza, modelovanie a simulácia vibrácií vo výrobných systémoch s technológiou vodného prúdu, Dizertačná práca. Prešov, 2012. 303 p.

[7] FABIAN, S., KRENICKÝ, T.: Využitie vybraných vibrodiagnostických metód v monitoringu prevádzkových charakteristík strojových zariadení. Spravodaj ATD SR. 2010 č. 1, 2. pp. 3234. ISSN 1337-8252

[8] PANDA, A., PRISLUPČÁK, M.: Technologické faktory pôsobiace na obrábanie. Trendy a inovatívne prístupy v podnikových procesoch : 16. medzinárodná vedecká konferencia. 2013 pp. 1-7. ISBN 978-80-553-1548-5 